\title{
English Vowel Acquisition through Songs by the Children in TK Madra Luisa Waiwerang
}

\author{
Yohana Venensia Bidi Lua ${ }^{1}$, I Nengah Sudipa ${ }^{2}$, Ni Made Dhanawaty ${ }^{3}$ \\ Venensabidi18@gmail.com \\ Universitas Udayana, Denpasar 80114, Indonesia
}

\begin{abstract}
This study is entitled English Sounds Acquisition through Songs by the Children in TK Madra Luisa Waiwerang. It aims at identifying the English vowel acquisition through songs by the children in TK Madra Luisa Waiwerang. Besides, this study also investigates the process of vowel acquisition through songs by the children in TK Madra Luisa Waiwerang. The data of this study were obtained from the results of a pronunciation test conducted on the children in TK Madra Luisa Waiwerang, East Flores, Indonesia. The test was done by asking students to briefly pronounce the vowels contained in English songs. The observation method was used to obtain the data from oral material (speaking performance). A note-taking technique was applied to mark down the relevant data for the study. The data of the study were qualitatively analyzed based on the theory of vowels by Mc Mahon (2002), and the process of language acquisition by Bialystok (1980). The analysis of this study was presented in informal methods. In the informal method, each problem in this study was presented narratively to make the analysis understood easily. The findings revealed that the acknowledgment of the student's language ability depended on the acquired stimulus and based on language system device to process the English vowels found in English songs which made the students were able to produce all English vowels. To contain the process of English vowel acquisition, the teachers provided stimulus such as giving instructions and questions related to the songs and the students responded by answering the questions and acting based on instructions given.
\end{abstract}

Keywords: English Vowel, Acquisition, English Songs, Children

\section{Introduction}

In their life, humans as social beings, including children, need tools to be able to communicate with each other. Language enables people to communicate with other people, either verbally, in writing or through signs. Thus, everyone should try to improve the mastery of the language maximally so that they can communicate well with others. Hence, Triadi (2017: 2) argues that language has the most important function in human life. Apart from being a means of communication, language has a function as a factor in assessing a person's intellectuality. 
The process of acquiring children's language can be influenced by external factors and from factors within the child himself. Language acquisition obtained from external factors has a very close relationship and is influenced by the play environment (with friends of the same age), the family environment, and also the school environment because their children will find many new things that are found in the vocabulary by introducing objects or events that are around. Humans as social beings need other people to meet their needs in interacting with everything that exists. Through environmental factors, children can explore language knowledge. The further influence of factors in the child, which means that a child is born with the genetic capacity to acquire the language that is around them. The acquisition of language for each child is different because humans are living things with varying characteristics, are unique, and have different abilities.

The process of acquiring English sounds will be ideal if it is started at an early age in the age range 0-6 years. At this time, the development of the child's brain has accelerated the development of $80 \%$ of the total adult brain. Suyadi (2010: 8) adds that all potential and intelligence as well as the basics of a person's behavior have begun to form at this age, so this period is often referred to as the golden age. As stated by Morrison (2012: 223) that children aged 4-6 years have a golden period to learn their mother tongue and foreign languages. They are able to learn some languages like native speakers and so during this period they should be put to the best of them. Children's language skills can develop rapidly during preschool such as the acquisition of sounds in vocabulary, when children pronounce a vocabulary correctly, the child indirectly learns about pronunciation in English.

Meanwhile, One of the media applied by the teacher is to use children's English songs. Songs are a source of authentic language. This is supported by the opinions of linguists and the experiences of English teachers because English songs can help teachers to create active, creative and fun learning. The songs applied as a technique or media in the process of English sounds acquisition because there is no time limitation in the use of song to stimulate the children in acquiring the target language. This means that, the students can use the songs as the language input anytime, whenever and wherever they will. Naturally, the children are being faster to remember the English sounds contained in English songs and they are willingly enjoying the process of language acquisition. Related to the English is the foreign language learned in Indonesia, then the process of this target language acquisition have to be conducted step by step.

TK Madre Louisa Waiwerang located in East Flores is one of the schools that applied English and Indonesian songs as the media in a formal teaching-learning process. Based on the data gained, the level of language acquisition for each students in the same class were different even though the teachers provided the same stimulus at the same place and time. Hence, the possibility of appropriated and enjoyable material must be an important concern for teachers to have a successful teaching process, especially in the process of acquiring the English language learning. Therefore, the focus on conducting this research was about English sound acquisition through song as the teaching media based on the process of teaching-learning in the classroom.

\section{Theoretical Framework}

\subsection{The Psycholinguistic in Language Acquisition}

Psycholinguistics is a branch of linguistics that often opens itself up to help interpret language acquisition problems as well as language comprehension and production. Dardjowidjojo (2005) mentions in detail that psycholinguistics studies four main topics: (1) comprehension, namely the mental processes that humans go through so that they can grasp what people say and understand what is meant, (2) production, namely the processes in which our mental self that enables us to speak as we speak, (3) the biological and neurological basis that enables humans to speak and (4) language acquisition, namely how children acquire their language. 
Psycholinguistics also tries to understand whether there is biological evidence that language is natural as proposed by Noam Chomsky (1959) with his transformative generative linguistic theory. Generative linguistics believes that language is a mirror of human thought and the result of the intelligence of every human individual who is always new.

In its development, humans experience a learning phase. In this phase, humans are faced with mastering a second/foreign language. Of course, mastery is more likely through the learning process, but in the study of language learning, there is a process of acquiring a second/foreign language when the learner learns it. Therefore, the term second language acquisition or foreign language acquisition emerged, which is rooted in the theory of first language acquisition and distinguishes between the language learning process and the acquisition process. Even though the process of acquiring a second language/foreign language starts from the learning process (Syahid, 2015: 89). The second language acquisition phase, of course, is based on theories of first language acquisition. The process of acquiring the first language in children is closely related to the social development of children and therefore also closely related to the formation of social identity.

\subsection{Language Acquisition Theory}

\section{A. Behavioristic Theory}

Behaviorism means a flow in psychology with its research object is something that can be sensed, namely observable visible behavior. In the operant habituation theory of behaviorism. The first is the respondent's behavior. In this behavioral phase, the reactions arise spontaneously as soon as the stimulus appears. The second is operant behavior. In this phase, the stimulus is not raised but arises from the organism itself (Shahid, 2015: 92). There are several external factors based on behaviorism theory that are important in the language learning process, namely (1) frequency, (2) imitation, and (3) reinforcement.

However, if then the child can speak, it is not because of "rule-governed" because the child cannot express the rules of language, but is formed directly by factors outside of himself. In this case, the behaviorists do not acknowledge the view that children master the rules of language and have the ability to abstract the important features of the language in their environment. They argue that stimuli from certain environments strengthen children's language skills. Children's language development is seen as a progression from randomly acting verbal disclosure to the actual ability to communicate through the S-R linkage principle (stimulus-response) and the imitation processes.

\section{B. Bialystok Theory}

Bialystok (1980), in his theory, wants to answer (1) why certain people succeed in learning a second language (L-2) and others fail and (2) why some people are strong in mastering certain aspects of L-2, while others are strong in other aspects. There are three stages in L-2 learning, namely (1) input, (2) knowledge, and (3) output. Input is the learner's experience (language exposure). Knowledge is all kinds of information and experiences obtained by learners. After all the cells in the knowledge stage are filled, then the output stage arrives in the form of a response as an understanding or utterance of the heart's content. Response (R) refers to the output.

\section{Nativism Theory}

According to Syahid (2015: 94) that Chomsky and his mentalists (Nativism) believe that every normal human being born in the world has been equipped with a tool to acquire language, namely the language 
acquisition device (LAD). So what is brought from birth is only the tool. Based on these abilities students can classify data or process input data in such a way that the data can be grouped carefully and simultaneously make grammatical rules. Meanwhile, what language the child will acquire is determined by the natural surroundings (Nature), which is determined by the input of the language used by the community around the growing child. So if a child is isolated from birth and not given language input, then this child does not acquire the language or in other words, this LAD does not get the input as it should. Chomsky in Syahid (2015: 94) says that children acquire language that is not like an empty plate, they acquire language just like they gain the ability to stand and walk.

Furthermore, Chomsky (1959: 35) states that language is not only complex but also full of errors and deviations in the rules of pronunciation or implementation of the language (performance). Chomsky also continued, language can only be mastered by humans, and children are born equipped with LAD. This tool is a biological gift that has been programmed to detail the possible grains of grammar. Chomsky's opinion above is based on several assumptions. First, language behavior is inherited (genetic), each language has the same developmental pattern (is something universal), and the environment has a small role in the process of language maturation. Second, the language can be mastered in a relatively short time. Third, the child's language environment cannot provide sufficient data for adult mastery of complex grammar. Thus, language is something that is complex and complicated so that it is impossible to master it in a short time through "imitation".

\section{Piaget's Cognitive Theory}

Jean Piaget in his theory of cognitive growth states that language development follows the path of cognitive development or thought. In his theory, Piaget argued that it was thought that formed language. In this case, a language is produced as a result of a thought process so that aspects of the language would not exist without a thought process. To prove the relationship between language and thought, there are two kinds of modes of thought, namely directed thoughts or intelligent thoughts and autistic thoughts. According to Piaget, cognitive growth stems from innate abilities.

According to the theory of cognitive growth, a child learns something through his actions that he gets from observing the world. From these actions, language is born. Cognitive activity is a form of individual action or behavior that is described and in sensorimotor activities which are also called language behavior. Regarding the relationship between language and thinking activities, Piaget stated two important things, namely as follows. First, the source of intellectual activity is not in language, but in the sensorimotor period, namely a schematic system. Second, the growth of cognition coincides with language acquisition, where a child first understands the objects he sees, then raises the symbolic function. These symbols are in the form of language. The first speech of language comes out related to and together with the game of symbols, imitation, and mental images (Chaer, 2009: 55).

\subsection{The Nature of Language in the Early Childhood}

According to Keraf (2009: 1), language is a means of communication between community members in the form of sound symbols produced by human speech tools. Because language is a very important communication tool, every student, especially in early childhood education, language is very important and must be given appropriately in learning, so that children can better master the functions of the language. From this description, it can be concluded that Early Childhood language is a series of sounds that symbolize the thoughts, feelings, and attitudes of children who are used to communicate both conveying wishes, thoughts, hopes, and requests for others. 


\subsection{Phonetic}

Phonetics is a branch of the study of phonology that studies the sounds of language regardless of whether these sounds have a function as a differentiator of meaning or not Chaer (2003: 102). Muaffaq (2012) argues that phonetics is the science that studies the sounds of language, which includes production, transmission, and perception of it, without paying attention to its function as a differentiator of meaning. Marsono (1999: 1) argues that phonetics is a science that investigates and tries to formulate regularly the sound of language, how to form it, what is its frequency, intensity, its timber as air vibrations, and how sound is received by the ear. Verhaar (2004: 10) states that phonetics is a branch of linguistics that examines the "physical" basis of language sounds.

Chaer (2003) divides the sequence of processes in which language sounds occur, into three types of phonetics, namely: a) Articulatory phonetics or organic phonetics or physiological phonetics, which studies how the mechanisms of human speech organs work in producing language sounds and how these sounds classified. b) Acoustic phonetics studies the sound of language as a physical event or natural phenomenon (the sounds are investigated for their natural frequency, amplitude, and intensity. c) Auditory phonetics studies how the mechanism for receiving the sound of the language sounds by the ear. The three types of phonetics that will be discussed in this study are articulatory phonetics. According to Ladefoged (1992) quoted in https://sinta.unud.ac.id articulatory phonetics is a branch of phonetics that investigates sound based on its speech tools/articulator.

\section{Methods}

The research design was a descriptive qualitative research. in conducting this research, the researcher focused on analyze and describe the process of acquiring the sounds of English vocabulary through English Practice Song by the children in Madre Louisa Kindergarten Waiwerang, East Flores. Data collection used to gather and collect data. In this step, gathering and collecting data were test, interview, observation, and documentation. Those techniques used to get the data to answer the research problems.

According to Sugiyono (2012: 59) quoted from www.repository.upi.edu, the main instrument of qualitative research is the author himself. In collecting data in the field, researchers were assisted by interview guidelines where in this study the authors conducted interviews with Kindergarten teachers Madre Louisa regarding the learning process in class and the use of songs as a learning medium in the process of acquiring English vocabulary in early childhood at the school. In this study, researchers used recording tools and Praat software as tools for analyzing English sounds produced by students as well as documentation tools which are one way of collecting data by archiving or documenting all forms of research data carried out. As a means of supporting this research, documentation in the form of photographs during the activity. This is done to make it easier for researchers to collect the data.

\section{Result and Discussion}

\subsection{English Sounds Obtained by Kindergarten Children through Songs}

\section{A. English /i/ vowel}

Vowels /i/ were found in several words of several English children's songs used by the researcher in data collection. The words that contain high front vowels in English are found in the words kness, january, three, and alphabets ( $\mathrm{b}$ and $\mathrm{g}$ ). Based on the formant data in the table above, students are able to produce the vowel sound /i/ as the front high vowel in English. Researchers found that there were 5 (62.5\%) students who were 
equally able to produce high vowels /i/ in the words knees and january. This is evidenced by the value of the first formant frequency (F1) which lies in the range of numbers lower than 400 and the second formant frequency (F2) is more than 2000 which describes the normal number of the high front vowel sound /i/ in English.

In addition, $3(37.5 \%)$ other students replaced the high front sound contained in the two words knees and january with a lower front vowel sound with a higher F1 frequency value than the highest vowel sound with the second formant frequency ( f2) is lower than 2000. Furthermore, in word three, all students were able to produce a high front vowel /i/ as evidenced by frequency of F1 is in the range of numbers less than 400 and the second formant frequency (F2) is more than 2000 which describes numbers normal sound of the front high vowel /i/ in English. There is also data found that in the realization of the letter " $\mathrm{g}$ " in English, 6 (75\%) students were able to produce high front vowels /i/. In the realization of the letter "b", there were 5 students who were able to produce a high front vowel with a description of the lowest F1 formant frequency. In addition, in the word February, only 4 (50\%) students were able to produce a high front sound /i/ in English.

To Compare the students' inconsistency of producing high front vowels /i/ on 6 words in English provided by the researcher, the first (1), third (3), and fifth (5) students were able to produce high front vowels /i/ in all language words The English contained in the children's song as evidenced by the frequency of the student's F1 is at the lowest score. This is inversely proportional to the data in the eighth student (8) who was only able to produce a high front vowel /i/ in word three and the seventh student (7) which was not much different was only able to produce a high front sound /i/ with the formant frequency F1 and F2 in the normal range.

\section{B. English /I/ Vowel}

The vowel sound /I/ is one of the high front sounds after the /i/ sound in English with a frequency range of F1, namely 400-499 at a number higher than the high /i/ sound but not higher than the F1 range for the middle sound. In addition, the F2 frequency range of the high front sound /I/ is also lower, ranging from 1769 - 1920 compared to the /i/ sound based on the results of the analysis of sounds produced by native speakers.

In addition, in December there are 3 out of 8 students who have not been able to produce the /I/ sound in English because the three students tend to replace the sound [I] which is the front middle-high sound with the sound [i] which is a sound. vowel high front (front-high). Furthermore, 7 (62.5\%) out of 8 students were able to pronounce the sound $/ \mathrm{I} /$ in the word twinkle. In addition, 6 out of 8 students were able to pronounce the /I/ sound in the word bingo. Meanwhile, three students made mistakes in pronouncing the words Indian and six with different students. In this word, the students tended to replace the sound $/ \mathrm{I} /$ with a high front sound $/ \mathrm{i} /$ as evidenced by a lower F1 frequency. In addition, only $4(50 \%)$ students were able to produce the sound /I/ in the word his. Meanwhile, the other four students replaced the sound with a higher sound as evidenced by the lower F1 and higher F2 frequencies.

\section{English /\&/ Vowel}

The vowel $/ \varepsilon /$ in English is a low front middle sound. Based on acoustic-phonetic data, an F1 frequency data that is higher than the F1 high sound /I/ frequency indicates a low middle / $\varepsilon /$ sound. In this case, the F1 frequency is in the range of $550-600 \mathrm{~Hz}$ and is not higher than F1 for the lowest front sound. To indicate the front sound, the frequency F2 for the sound / $/$ / ranges from 1770-2000 Hz. Based on the order of words in the table above, only 1 out of 8 students made a mistake with the word there by substituting the / $\varepsilon /$ sound as the lower front sound with the higher F1 frequency. In addition, the sound $/ \varepsilon /$ contained in the three English words ten, seven, and the letter ' $n$ ' is pronounced with a higher F1 frequency indicated a low front sound /æ/.

Furthermore, in the three names of February, September, and December, there were 3 out of eight students who also pronounced the lower sound, namely /æ/ with the higher frequency of $\mathrm{f} 1$. The three students who substituted the /\&/ sound for the low /æ/ sound in the word February also did the same thing with the word 
December. However, the word head was the word with the highest number of mistakes made by four students, these students also substituted the $/ \varepsilon /$ sound for a low /æ/ sound.

\section{English /æ/ Vowel}

The /æ/ vowel sound in English is the lowest front sound with the highest F1 frequency range compared to other front vowels. Also, the frequency range of F2 between 1660-1900 Hz indicates that this vowel sound is a front vowel sound. F1 data shows that the first student is able to produce the lowest sound /æ/ as evidenced by the F1 frequency range at normal numbers. In producing this low front $/ \mathfrak{a} /$ sound, students tended to replace it with a higher sound with a lower frequency range F2. In word and and January, only 3 (37.5\%) of 8 students were able to produce F1 frequencies in the normal range of numbers, while the other 5 students replaced the sound /æ/ with a higher vowel sound. The same thing happened to the word has that there were 5 students replaced this low front sound with a higher sound. In other words, only $5(62.5 \%)$ of the 8 students were able to produce a sound /æ/ in the F1 frequency range at normal numbers.

\section{E. English /a/ Vowel}

The sound /ə/ in English is the middle sound. Based on formant data, this middle sound has a frequency value of F1 in the range of 500-600 Hz. In addition, this middle vowel sound has a frequency of F2 in the range of 1500-1750 Hz. Based on the data from the analysis of the middle vowel sound in English three words. In April there are 6 out of 8 students who are able to pronounce the sound /ə/ with frequency values F1 and F2 in the normal range. In addition, there were 3 students who made mistakes in pronouncing the middle vowel sounds with a range of F1 and F2 that were higher than the normal range. Whereas in the word the, it was noted that all students were able to produce the sound /a/ which is the middle vowel in English. In this case, the F1 frequency was higher than the normal range, which was more than $600 \mathrm{~Hz}$.

\section{F. English $/ \Lambda /$ Vowel}

The vowel $/ \Lambda /$ in English is the middle sound as opposed to the /a/ sound. The sound /a/ in English is pronounced without any stress on the intonation, while the sound $/ \Lambda /$ is pronounced with the stress on the intonation in a word. Based on the F1 frequency, the center $/ \Lambda /$ sound ranges from 650-690 Hz. The F2 frequency for this middle vowel sound ranges from 1200-1800 Hz. Formant data shows that the first and eighth students can produce a middle sound $/ \Lambda$ / on each word in the table with a frequency of $F 1$ in the range not higher than $690 \mathrm{~Hz}$ and not lower than $650 \mathrm{~Hz}$. The two students also pronounced the sound $/ \Lambda /$ with the formant frequency in the normal range for the middle vowel sound.

Furthermore, 7 (87.5\%) out of 8 students pronounced the middle vowel sound $/ \Lambda /$ in the word one with an F1 frequency not higher than $690 \mathrm{~Hz}$, while one other student pronounced the $/ \Lambda$ / sound with a higher F1 frequency. in the same case, there were two students who pronounced the middle vowel sound $/ \Lambda /$ with an $\mathrm{F} 1$ frequency higher than $690 \mathrm{~Hz}$ in the word up. Furthermore, there were $5(62.5 \%)$ out of the 8 students were found to pronounce the middle vowel $/ \Lambda$ / in the $\mathrm{F} 1$ range not higher than $690 \mathrm{~Hz}$ when compared to the other 3 students. As for the word wonder, it was recorded that 4 out of 8 students were able to pronounce the sound $/ \Lambda /$, and 4 other students pronounced it wrong. In addition, the frequency of F2 in the middle vowel sound $/ \Lambda /$ is pronounced in the normal range, which is not lower than $1200 \mathrm{~Hz}$ and not higher than $1800 \mathrm{~Hz}$.

\section{G. English /a/ Vowel}

The sound / $/ 2 /$ in English is a middle vowel sound with a frequency of F1 in the numbers 500-600, where this frequency is not lower than the frequency of high vowel F1 values and is also not higher than the F1 frequency on low vowels. Besides that, the F2 frequency for this middle vowel sound lies in the range of 1300-1500 Hz. In this case, the first student was able to sound the middle vowel / $/$ in each word provided by 
the researcher in English, this is evidenced by the F1 formant value ranging from 500-600 Hz. In this case, the F2 frequency data is recorded in accordance with normal F2, students are able to produce a middle vowel sound $/ 2 \%$. In addition, based on the list of words used as data in obtaining students' ability to produce vowels in English, the word december is the word with the least number of errors made. In this case, $7(87.5 \%)$ of the 8 students had an F1 frequency in the middle vowel range, which is 500-600 Hz. The next, the sound / $/$ in the word shoulder, September, November, and wonder, there were $6(75 \%)$ of the 8 students who were able to produce based on the F1 and F2 value data from the results of the acoustic-phonetic analysis. Besides that, the other $2(25 \%)$ students tended to replace producing the middle sound / r w with the higher F1 frequency. In pronouncing the middle sound / $/$ in the words farmer and October, 3 out of 8 students produced it with a frequency of F1 which was higher than the F1 frequency of the middle vowel. However, $5(62.5 \%)$ other students were able to produce sound / $/$ with normal F1 frequencies ranging from 500-600 Hz.

\section{H. English /u/ Vowel}

The vowel /u/ in English is a low back sound as is proven by the F1 frequency in the $310-400 \mathrm{~Hz}$ range and F2 in the 800-1000 Hz range. The frequency of the formant shows that some students are still inconsistent in producing the $/ \mathrm{u} /$ sound in the words june and $t w o$. The data obtained shows that there are three students producing a high back vowel with a higher formant range which indicates a lower sound than the /u/ vowel. The same thing also happened to the two students who produced the sound $/ \mathrm{u} / \mathrm{in}$ the word two. The formant data in the table shows that $62.5 \%$ of students have a frequency of $F 1$ which indicates the sound $/ \mathrm{u} /$ in the word june. Whereas in word $t w o$, there are $75 \%$ of students producing /u/ sound with normal F1 at a frequency of $310-450 \mathrm{~Hz}$.

Regarding the F2 frequency produced by students, it is located in the higher frequency range than the back vowel sound. Even so, the students were heard making a /u/ sound based on the data from the audio recording. Therefore, it can be said that the /u/ sound produced by students in the two words June and two is a high sound and tends to be in the middle compared to the normal sounds found in English. In this case, the normal F2 frequency for the pronunciation of the back vowel sound / $\mathrm{d} / \mathrm{in}$ English should be in the numeric range of approximately $800-1100 \mathrm{~Hz}$.

\section{English / / Vowel}

The vowel / $/$ in English is a high back sound but not higher than the /u/ sound. The back high vowel sound / $/$ is indicated by an F1 frequency that is higher than the high back sound /u/ in English, which is in the range of 451-500 Hz. While the F2 frequency ranges from $1050-1200 \mathrm{~Hz}$. Based on the sound formant data $/ \mho /$ in English produced by the students in the words July and you, there were $5(62.5 \%)$ students who pronounced the sound $/ \mho /$ with the F1 frequency located in the normal number range, while the other three students pronounced the sound $/ \mho /$ in the word July with a lower F1 frequency indicates a higher sound, namely the high volume behind $/ \mathrm{u} /$. In addition, there were $7(87.5 \%)$ out of 8 students pronouncing the sound $\mathrm{c} / \mathrm{in}$ the word you with the formant frequency F1 located in the normal range. Related to the frequency of F2 in the back sound $/ \mho /$, students also tend to pronounce it higher so that it is indicated in a more middle sound because the resulting F2 frequency is in the range of normal numbers, which is between 1050-1200 Hz.

\section{J. English / / Vowel}

Vowel / $\mathrm{\rho} /$ in English is based on the high and low of the voice, this vowel is a high-back vowel with a frequency of $\mathrm{F} 1$ in the $600-700 \mathrm{~Hz}$ range and F2 frequencies in the range of $800-1000 \mathrm{~Hz}$. Based on the results of the analysis of the sound produced by students on the vowel $/ \mathrm{\rho} /$ in the word four, there were 5 $(62.5 \%)$ of the 8 students pronouncing it with a frequency of F1 in a range that was not higher than the lower back vowel / $\mathrm{a} /$ and also not lower than the back high vowel. The frequency range F2 of the sound /o/ indicates 
a back vowel sound. In addition, the other 3 students tended to pronounce the sound /o/ with an F1 frequency lower than $600 \mathrm{~Hz}$.

\section{K. English /a/ Vowel}

Vowel /a/ in English is the lowest back-vowel with a frequency range of F1 not lower than $700 \mathrm{~Hz}$, while for $\mathrm{F} 2$ in the range not lower than $1100 \mathrm{~Hz}$ and not higher than $1500 \mathrm{~Hz}$. Based on the formant data produced by students on the low back sound /a/ in the words march, what, star, are, and farmer, there are $5(62.5 \%)$ students who pronounce the low back sound /a/ with an F1 frequency not lower than $700 \mathrm{~Hz}$ and F2 in the normal range. In addition, in the word october, it was found that $4(50 \%)$ of the 8 students recited the low back sound /a/ with a frequency of F1 that was not lower than $700 \mathrm{~Hz}$ and F2 in the normal range. In this word, 4 other students pronounced sound /a/ with a lower F1 frequency and an F2 frequency that was not higher than the F2 frequency range in the back vowel sound which was heard in the audio recording of the four students pronouncing the vowel sound $/ \mathrm{o} /$

Furthermore, the pronunciation of the low back vowel sound /a/ in the words dog, was, and august, it was found that only $3(37.5 \%)$ of 8 students pronounced the sound /a/ in the high F1 range as an indication of the lowest vowel sound. It is the same in the range of F2 which indicates the sound of a back vowel. In this case, the other 5 students tended to produce a low back vowel sound / $/$ / in the F1 frequency range indicating a higher back-vowel sound.

\subsection{The Process of Acquiring English Sounds Through Songs by the Children in Kindergarten}

In this discussion, the researcher discusses how the process of sound acquired process is based on the data found to answer the second research problem. In line with this, the data found in the field on the process of acquiring English sounds through song media are closely related to the process of providing stimulus and response. Where the teacher provides a stimulus to students and then the students respond. In general, this process is closely related to behavioristic theory in which the theory explains that the process of acquiring language is obtained through stimuli or the S-R linkage principle (stimulus-response) and the imitation process from a certain environment which can strengthen children's language skills. Based on the data it was found that the teacher provided a stimulus by providing directions or invitations to students such as warming up or brain storming, namely inviting students to line up in front of the class, making approaches by pronouncing vowel sounds, reading and pronouncing each word in the song lyrics according to the theme at each meeting, inviting students to sing English songs according to the theme given by the teacher and reciting every sound in the song lyrics that has been registered for recording by the researcher.

The data obtained shows that the teacher who acts as a facilitator in this research always provides strong motivation indirectly in acquiring English sounds because they always provide simple instructions related to daily activities that are usually carried out in the classroom using language that is easily understood by students. To contain the stimulus (input) given by the teacher, both simple directions or instructions that are easy to understand and the English song media in the process of obtaining the English vowel contained in each song lyrics can be used as knowledge through interaction activities among teachers and students that produce output. As previously explained, the stimuli as input material provided by the teacher are not only through simple instructions, but also by singing simple English songs which are of course in accordance with the development and age of the child. In the case of early childhood, which aims to introduce the numbers from the numbers 1 to ten in the ten little Indian song, introducing the parts of the body in the head and shoulder song, the universe in the twinkle-twinkle little star, pet in bingo song, the name of the month in a year in the months song. 
Based on the results of the study, it was found that students were able to do what the teacher instructed and were able to recognize, remember and sing every English song according to the theme by reciting or pronouncing every sound in the lyrics of the song given even though the pronunciation ability of each student was different. The students are very enthusiastic in the learning process, volunteering without any coercion or pressure from outside. Because singing activity is an activity that is carried out for the pleasure that is generated without considering the final result. In addition, singing can help early childhood achieve their development and as a natural way of understanding oneself, others and their environment. Furthermore, songs that are sung repeatedly during each activity in the classroom can provide information and develop imagination in early childhood.

According to Jean Piaget's cognitive theory regarding the growth of cognition, language development follows the path of cognitive development or thought. In this case, a language is produced as a result of a thought process so that aspects of the language would not exist without a thought process. Based on the data found from the first meeting to the fourth meeting that when the teacher does brain storming by asking questions, inviting students to sing songs according to the theme of the song given, such as the theme of body members with the title song head shoulder knees and toes, at that moment what the students think and express are the members of their body starting from the head, shoulders, knees, big toes, eyes, ears, mouth, and nose. Another finding of the months song shows that what students think and expose is about the names of the months in a year, namely January, February, March, April, May, June, July, August, September, October, November, and December. Moreover, in the pet-themed song bingo, the twinkle-twinkle little star song with the theme of the universe, the ten little Indians song with the theme of recognizing numbers where students are able to sing and pronounce the sounds in each verse. This shows that students are able to produce language through a thought process.

\section{Conclusion}

Based on the results of the study, the children at Madre Louisa Kindergarten were able to get all the English vowels even though the students inconsistently made mistakes in their pronunciation. Their ability in acquiring English vowels is proven by their ability to produce these vowels through children's songs sung in

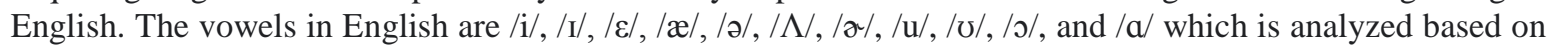
the F1 and F2 frequencies. Furthermore, regarding the process of acquiring English vowels, it is carried out with the theory of stimulus and response in the learning process in the classroom between students and teachers. In this case, the teachers provide a stimulus which is an input to the Language Acquisition Device owned by students, then the students produce it as an output or response to the stimulus given. Thus, the stimulus given through songs as a learning medium has a significant effect on the results or acquisition of English vowels.

\section{References}

Bialystok, E. 1980. On the Relationship between Formal Proficiency and Strategic Ability. Presented at the Annual Meeting of TESOL, March 1980, San Francisco, CA.

Chomsky, Noam. 1959. A Review of B.F. Skinner Verbal Behavior dalam language, 35. No.1

Chaer, Abdul. 2003. Linguistik Umum. Jakarta: Rineka Cipta.

Dardjowidjojo, S. 2005. Psikolinguistik: Pengantar Pemakaian Bahasa Manusia, Edisi Kedua. Jakarta: Yayasan Obor Indonesia.

Keraf, G. 2009. Diksi dan Gaya Bahasa. Jakarta: PT Gramedia.

Ladefoged, P. 1992. A Course in Phonetics (2nd ed). New York: Harcourt Brace Jovanovich, Inc.

Marsono. 1999. Fonetik. Yokyakarta: Gadjah Mada University Press 
Morrison, G. S. 2012. Dasar-Dasar Pendidikan Anak Usia Dini (PAUD). Jakarta: Indeks.

Muaffaq, A. N. 2012. Fonologi Bahasa Indonessia. Cet. I, Makassar: Alauddin University Press.

Sugiyono. 2012. Memahami Penelitian Kualitatif. Bandung: Alfabeta.

Suyadi. 2010. Psikologi Belajar Anak Usia Dini. Yogyakarta: Pedagogia.

Syahid. 2015. Bahasa Arab sebagai Bahasa Kedua (Kajian Teoritis Pemerolehan Bahasa Arab pada Siswa Non-Native). Arabiyat, Vol. 2, No.1, Pp (86-97).

Triadi, I. B. 2017. Studi Kasus Analisis Bahasa pada Anak Usia 4 Tahun (Kajian Psikolinguistik). Jurnal Sasiondo Unpam, Vol. 4, No. 1, Pp (1-16).

Verhaar, J. M. W. 2004. Asas-asas Linguistik Umum. Yokyakrta: Gadjah Mada University Press.

\section{Reference from Internet}

https://sinta.unud.ac.id/uploads/dokumen_dir/4e391eef4b3dcafac6a1a25118b52589.ppd 